\title{
Metoda retrogresji w geografii historycznej Polski (wybrane zagadnienia)
}

\author{
Henryk Rutkowski \\ https://orcid.org/0000-0003-0924-2455 \\ Warszawa
}

Zarys treści: Artykuł przedstawia materiał do dyskusji na temat zasad stosowania retrogresji w geografii historycznej. Wstęp zawiera charakterystykę tej metody. Główna część artykułu opiera się na doświadczeniach prac nad mapami szczegółowymi ziem polskich Korony w XVI w. Omówiono podstawę źródłową oraz treść tych map, zaznaczając stopień pewności lub prawdopodobieństwa przedstawionych elementów krajobrazu. Druga część obejmuje kilka innych przykładów z kartografii historycznej.

Słowa kluczowe: geografia historyczna Polski, metoda retrogresji, wody, lasy, osadnictwo, drogi, granice

Jak zaznaczono w tytule artykułu, nie jest on całościowym ujęciem tematu retrogresji, lecz zbiorem uwag odnośnie do wybranych zagadnień. Pierwsza część dotyczy doświadczeń wynikających z prac nad atlasem Polski XVI w., natomiast druga poświęcono kilku innym przykładom zastosowania metody retrogresji. Może być to przyczynek do dyskusji na temat tego, jaki jest lub jaki powinien być zakres i sposób stosowania tej metody.

Wiadomo, że cechą geografii historycznej jest szerokie stosowanie retrogresji, która polega na ustalaniu faktów wcześniejszych na podstawie faktów późniejszych. Mówiąc inaczej, jest to badanie, co w znanej przestrzeni geograficznej świadczy o przeszłości i umożliwia poznanie, jaki był jej stan w określonym dawnym czasie. Wymaga to odróżniania w krajobrazie elementów o długim trwaniu od takich, które zmieniają się szybciej.

Charakterystyka metody geograficzno-historycznej, którą w 1948 r. podał

Abstract: The article presents material for discussion on the principles of using retrogression in historical geography. The introduction presents the characteristics of this method. The main part of the article is based on the experiences of working with detailed maps of the lands of the Polish Crown in the $16^{\text {th }}$ century. The source basis and content of these maps are discussed, indicating the degree of certainty or probability of the presented landscape elements. The second part of the article includes several other examples from historical cartography.

Keywords: historical geography of Poland, retrogressive method, waters, forests, settlement, roads, borders

Aleksander Gieysztor, nadal jest aktualna. Wskazał on „na rolę retrogresji w badaniu krajobrazów naturalnego, kulturalnego i historyczno-politycznego. Polega ona na wychodzeniu badania z czasów późniejszych, do których posiadamy najpełniejsze materiały źródłowe (w praktyce polskiej przełom XVIII/XIX w.), i posuwaniu studium wstecz, przy uwzględnieniu źródeł coraz starszych i coraz szczuplejszych. Metoda ta zakłada wszędzie prócz opisu faktów konieczność ich tłumaczenia genetycznego. [...] Punktem wyjścia jest stan, którego znajomość spoczywa na stosunkowo mocnej podstawie i który wyłącza uproszczenia i opuszczenia zagadnień, [czyli] błędy płynące z milczenia źródeł co do okresów wcześniejszych" ${ }^{1}$.

\footnotetext{
${ }^{1}$ A. Gieysztor, Zarys nauk pomocniczych historii, t. 2, Warszawa 1948, s. 248. Wskutek braku odpowiedniej informacji w tym miejscu i w spisie treści błędnie przypisałem zacytowane zdania Stanisławowi Herbstowi, autorowi poprzedzającego tekstu o kartografii: H. Rutkowski, Stanisław Herbst (1907-1973), w: Szkoły, ośrodki i twórcy polskiej historii kartografii (1945-2015), red. T. Bogacz, B. Konopska, Warszawa 2016 (Z Dziejów Kartografii, 20), s. 162-163.
} 
Typowym postępowaniem badawczym jest łączenie retrogresji z wykorzystaniem źródeł, które zawierają bezpośrednie informacje $\mathrm{z}$ badanego okresu. Na ogół retrogresja nie jest metodą samodzielnego ustalania określonych faktów ${ }^{2}$. Podobnie jak we wszelkich badaniach historycznych, w geografii historycznej dochodzi się do wyników, które można uznać za pewne, oraz do takich, które mają różny stopień prawdopodobieństwa. W kartografii historycznej, służącej przedstawianiu badań z zakresu omawianej dyscypliny, ma na to wpływ skala map. To co na mapie szczegółowej jest oznaczeniem przybliżonym, na mapie w małej skali może być - ale nie musi - oznaczeniem pewnym. Gdyby np. jakaś granica była znana o tyle, że przebiega w obrębie pasa terenu o szerokości do $0,5 \mathrm{~km}$, to linia poprowadzona na mapie w skali 1:100 000 obarczona byłaby ryzykiem błędu do $5 \mathrm{~mm}$; przeniesienie znaku tej granicy na mapę w skali 1:1000 000 usuwa ten problem.

\section{Z prac nad „Atlasem historycznym Polski”}

Opracowywana w Instytucie Historii PAN seria „Atlas historyczny Polski. Mapy szczegółowe XVI wieku”, która ma objąć ziemie polskie Korony, liczy już sześć $\mathrm{z}$ ośmiu zaplanowanych tomów (wydano je w latach 1966-2017) i bliska jest ukończenia. Część pierwsza każdego z woluminów obejmuje kartografię: mapę główną, mapy dodatkowe oraz plany wybranych miast, druga natomiast zawiera obszerny komentarz i rozbudowane indeksy. $\mathrm{Z}$ uwagi na ponad pół wieku prac nad tą serią widać znaczące różnice między kolejno wydawanymi tomami (kolejność ich ukazywania się nie odpowiada numeracji tomów), ale zakres treści mapy głównej, który wyrażają oznaczenia podane w legendzie, pozostał bez zmian. Mapa główna w skali 1:250 000 przedstawia wszystkie

\footnotetext{
2 Por. S. Arnold, Geografia historyczna, jej zadania i metody, „Przegląd Historyczny", 28 (1), 1929, s. 115-117; J. Topolski, Metodologia historii, Warszawa 1968, s. 328.
}

miejscowości, które istniały na prezentowanym obszarze w drugiej połowie XVI w., zróżnicowane pod względem kategorii prawnej i gospodarczej (miasta, wsie, osady młyńskie, osobne folwarki itd.), a także wielkości i przynależności własnościowej (własność królewska, kościelna, szlachecka i miejska). Wyróżniono przy tym miejscowości, które mają określone znaczenie w terytorialnej strukturze administracji państwowej i kościelnej, oraz oznaczono granice państwa, województw, ziem i powiatów. W odniesieniu do Kościoła katolickiego (łacińskiego) oznaczono granice diecezji, archidiakonatów i parafii. Mapa pokazuje też ważniejsze drogi istniejące w XVI w. Pod względem chronologicznym opracowanie obrazuje przede wszystkim stan z końca XVI stulecia. Jeżeli w ciągu półwiecza nastąpiła zmiana, to mapa przedstawia stan późniejszy ${ }^{3}$.

Podstawowymi źródłami do odtworzenia osadnictwa i granic administracji państwowej są rejestry poborowe, czyli rejestry podatku nadzwyczajnego zwanego poborem, który był każdorazowo uchwalany przez sejm. Podatek spisywano w rejestrach poszczególnych powiatów, z reguły wymieniając miejscowości według podziału na parafie, które służyły wówczas skarbowi państwa jako najmniejsze jednostki terytorialne. $Z$ innych źródeł pisanych za najważniejsze należy uznać akta wizytacji kościelnych, zawierające pewniejsze informacje o zasięgu parafii ${ }^{4}$.

Mapa główna przedstawia trzy elementy środowiska przyrodniczego: rzeźbę terenu, sieć wodną i zalesienie. Pierwszy obrazowany jest za pomoca poziomic i punktów wysokościowych. Ponieważ zmiany lokalne, które mogły zajść w tym zakresie,

\footnotetext{
${ }^{3} \mathrm{H}$. Rutkowski, Work on the historical atlas of the sixteenth-century Poland, „Polish Cartographical Review”, 50 (4), 2018, s. 223-231. W wersji polskiej: tenże, Prace nad atlasem historycznym Polski XVI wieku, „Polish Cartographical Review. Suplement w języku polskim”, 3 (2), 2018, s. 243-248.

${ }^{4}$ M. Stoń, Źródła pisane, w: Wielkopolska w drugiej połowie XVI wieku, red. K. Chłapowski, M. Stoń, oprac. A. Borek i in., Warszawa 2017 (Atlas historyczny Polski. Mapy szczegółowe XVI wieku, 4), s. 20-28.
} 
nie wpływają na sytuację pokazaną w skali 1:250 000, przejęto ten element fizjografii z map dzisiejszych. Zupełnie inaczej wygląda sprawa oznaczenia wód i lasów, które przedstawiono według stanu $\mathrm{z}$ przełomu XVIII i XIX w., gdyż wcześniejszego nie można rozpoznać dostatecznie szczegółowo. W legendzie mapy głównej odpowiednie znaki umieszczono pod określeniem: „topografia (stan z przełomu XVIII i XIX w.)". Czytelnik jest zatem uprzedzony, że obraz środowiska jest o dwa wieki późniejszy niż pokazane na jego tle osadnictwo i granice. Podstawę opracowania fizjografii stanowią te źródła kartograficzne omawianego atlasu, które mają charakter kartometryczny i są dostatecznie szczegółowe.

$\mathrm{Na}$ pierwszym miejscu wymienia się wśród źródeł kartograficznych mapy poszczególnych województw w granicach Rzeczypospolitej po pierwszym rozbiorze (1772), które pokrywają znaczną część rdzennie polskiego obszaru Korony. Ich autorem był Karol Perthées, nadworny kartograf króla Stanisława Augusta Poniatowskiego. Na sporządzonych w skali 1:225000 mapach oznaczone zostały wszystkie miejscowości, a także granice państwa, województw, ziem i powiatów. Położenie osiedli i przebieg granic są niedokładne, ponieważ mapy Perthéesa nie spełniają warunków kartometryczności, ale wybrane elementy ich bogatej treści mogą podlegać transpozycji na mapy dzisiejsze (dawniejszej transpozycji odpowiada obecnie kalibracja map). Nie można tego natomiast zrobić z elementami powierzchniowymi, w szczególności lasami 5 .

Na przełomie XVIII i XIX w. ziemie Polski zabrane przez państwa ościenne zostały pokryte mapami austriackimi i pruskimi, których dokładność zbliżona jest już do map szczegółowych z XX w. Po ustanowieniu w 1815 r. nowych granic politycznych doszła do tego Topograficzna

${ }^{5}$ H. Rutkowski, Mapy Perthéesa, w: tenże, Fundamenta historiae. Pisma wybrane, red. M. Zbieranowski, M. Stoń, Warszawa 2014, s. 269-282. karta Królestwa Polskiego, znana jako mapa Kwatermistrzostwa ${ }^{6}$.

Wymienione mapy - służące za podstawę przedstawienia rzek, jezior, stawów, bagien i gruntów podmokłych - powstały przed prowadzonymi na dużą skalę pracami regulacyjnymi i melioracyjnymi. Koryta małych rzek, zwłaszcza płynących wąskimi dolinami, z reguły nie ulegają przesunięciom (wyjątkiem są cieki płynące przez mokradła). Inaczej jest z rzekami dużymi. Oto odpowiedni fragment komentarza z tomu obejmującego Wielkopolskę. Rzeki tej historycznej krainy są typowo nizinne, o niewielkim spadku. „Niewielki spadek utrudniał szybki spływ wód wezbraniowych, które czasami zajmowały cała szerokość terasy zalewowej. W przypadku Noteci to obszar osiągający od ok. 2 do nawet $8 \mathrm{~km}$ szerokości. Tworzące się w okresie wezbrań liczne nowe odnogi i ramiona powodowały częste zmiany przebiegu głównego koryta rzeki. Dawne źródła kartograficzne pozwoliły uchwycić znaczące różnice $\mathrm{w}$ przebiegu rzeki [Noteci]. Oczywiście należy pamiętać, że od końca XVI stulecia do chwili wydania wspomnianych map źródłowych upłynęło jeszcze dodatkowe 200 lat i obraz tych map prawdopodobnie w różnych miejscach jest daleki od stanu XVI-wiecznego. Potwierdzeniem są uchwycone duże różnice, do których doszło w okresie zaledwie ok. 130 lat, jakie upłynęły od początku XIX w. do wydania map WIG". Chodzi tu o wydawane w okresie międzywojennym przez Wojskowy Instytut Geograficzny mapy topograficzne w skali 1:100 000, które posłużyły za podstawę opracowania w skali 1:250 $000^{7}$.

Obraz rzek z przełomu XVIII i XIX w. został w niewielu miejscach zmieniony na podstawie wcześniejszych źródeł. Największą zmianą jest odtworzenie na wiek XVI koryta Sanu przy ujściu do Wisły. Jak

\footnotetext{
${ }^{6}$ Tenże, Źródła kartograficzne, w: tenże, Fundamenta, s. 283-297; T. Panecki, Źródła kartograficzne, w: Wielkopolska, s. 29-37.

${ }^{7}$ E. Rutkowska, Środowisko geograficzne, w: Wielkopolska, s. 41-42.
} 


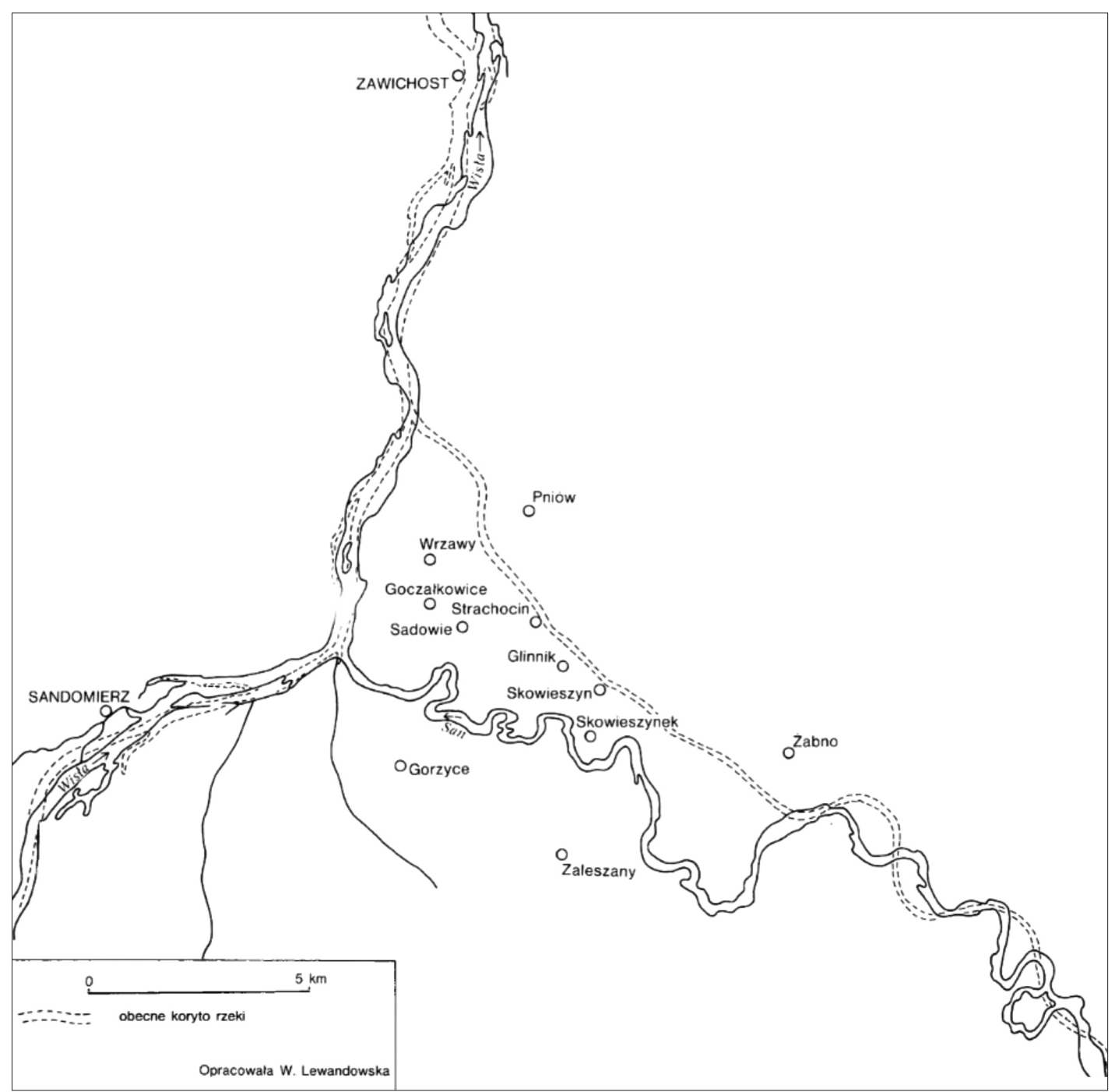

Mapa 1. Ujście Sanu do Wisty, oprac. W. Lewandowska.

Źródło: K. Chłapowski, „Środowisko geograficzne”, w: „Województwo sandomierskie”, s. 26

świadczą źródła z XV i XVI w., odcinek ten wyznaczał granicę między województwami sandomierskim i lubelskim. $\mathrm{Na}$ początku XVIII w. nastąpiło duże przesunięcie koryta rzeki na północ, co spowodowało, że kilka wsi z prawego brzegu znalazło się na lewym. Zgodnie z polskim prawem granica wojewódzka nie uległa jednak zmianie (mapa 1$)^{8}$.

${ }^{8}$ Województwo lubelskie w drugiej połowie XVI wieku, red. W. Pałucki, oprac. S. Wojciechowski, Warszawa 1966 (Atlas historyczny Polski.
Modyfikacje stanu pokazanego w źródłach kartograficznych nastąpiły również w przypadku jezior i stawów. Na mapie województwa krakowskiego pokazano (zlokalizowane w przybliżeniu) rozległe stawy w okolicach Oświęcimia, Zatora i rzeki Soły. W Wielkopolsce przedstawiono

Mapy szczegółowe XVI wieku, 3), s. 18; Województwo sandomierskie w drugiej połowie XVI wieku, red. W. Pałucki, oprac. K. Chłapowski i in., Warszawa 1993 (Atlas historyczny Polski. Mapy szczegótowe XVI wieku, 2), s. 25, 26 (mapa). 
natomiast skupiska nawet niewielkich jezior i stawów, ponieważ umożliwiły to źródła zawierające drobiazgowe opisy granic między dobrami różnych właścicieli ${ }^{9}$.

W polskiej geografii historycznej od dawna panuje pogląd, że odtworzenie stanu zalesienia dla okresu wcześniejszego niż schyłek XVIII w. nie ma podstaw ${ }^{10}$. Takie stanowisko zajęli również autorzy mapy województwa płockiego ok. 1578 r. w skali 1:200 000, wydanej w roku 1958, czyli jeszcze zanim powstała inicjatywa podjęcia prac nad omawianą tu serią ${ }^{11}$. Szczegółowej rekonstrukcji stanu zalesienia w XVI w. można dokonać tylko wobec takich rejonów, dla których istnieje wystarczający zasób źródeł pozwalających na zastosowanie retrogresji. Przykładu dostarcza praca Tomasza Związka i Tomasza Paneckiego o okolicach Nowego Tomyśla ${ }^{12}$. Całościowy obraz lasów w skali 1:250 000 mógłby kiedyś posłużyć za podstawę do retrogresji np. na mapie 1:1000 000, gdzie wraz z kartograficzną generalizacją zmalałyby błędy szczegółów, a wzrosłaby dokładność.

Przytoczone wyżej określenie znaków topograficznych w legendzie mapy głównej (,stan z przełomu XVIII i XIX w.”) $\mathrm{w}$ pełni dotyczy lasów oraz bagien i gruntów podmokłych. Informację o rzekach i jeziorach trzeba natomiast sprecyzować trochę inaczej. Chociaż sieć wodna jest

\footnotetext{
${ }^{9}$ Województwo lubelskie, s. 18-21; J. Humnicki, K. Pacuski, Środowisko geograficzne, w: Mazowsze w drugiej połowie XVI wieku, red. W. Pałucki, oprac. A. Dunin-Wąsowiczowa i in., Warszawa 1973 (Atlas historyczny Polski. Mapy szczegółowe XVI wieku, 7), s. 29-31; K. Chłapowski, Środowisko geograficzne, w: Województwo sandomierskie, s. 25-28; M. Wilska, Środowisko geograficzne, w: Województwo sieradzkie i województwo tęczyckie w drugiej połowie XVI wieku, red. H. Rutkowski, oprac. K. Chłapowski i in., Warszawa 1998 (Atlas historyczny Polski. Mapy szczegółowe XVI wieku, 5), s. 22-23; E. Rutkowska, Środowisko geograficzne, w: Województwo krakowskie w drugiej połowie XVI wieku, red. H. Rutkowski, oprac. K. Chłapowski i in., Warszawa 2008 (Atlas historyczny Polski. Mapy szczegółowe XVI wieku, 1), s. 23-25; E. Rutkowska, Środowisko geograficzne, w: Wielkopolska, s. 41-43.

${ }^{10}$ S. Arnold, Geografia, s. 101-102; A. Gieysztor, Zarys, s. 229.

${ }^{11}$ Województwo płockie około 1578 r., red. S. Herbst, oprac. I. Gieysztorowa i in., Wrocław 1958 (Atlas historyczny Polski. Seria A: Mapy szczegółowe, 2), s. 44.

${ }^{12}$ T. Związek, T. Panecki, Osadnictwo olęderskie w badaniach nad rekonstrukcją szesnastowiecznego zalesienia na przykładzie okolic Nowego Tomyśla, „Studia Geohistorica”, 5, 2017, s. 29-62.
}

na ogół pokazana zgodnie ze źródłami kartograficznymi ze wskazanego czasu, to jednak miejscami odtworzony został stan wcześniejszy. Wydaje się więc, że obraz rzek i jezior wolno określić jako stan z XVI w. uzyskany metodą retrogresji. Dla małych cieków można ten stan uznać za prawie pewny, a dla dużych rzek - za prawdopodobny, w różnych miejscach w różnym stopniu (im szersza dolina, tym mniejsze prawdopodobieństwo).

Wśród elementów oznaczonych na mapie głównej najważniejsze jest osadnictwo i to ono zdecydowało o wielkości skali. Miejscowości zlokalizowane są zgodnie $\mathrm{z}$ położeniem pokazanym na mapach z XVIII i XIX w. W większości nie ma tutaj różnic $\mathrm{w}$ porównaniu $\mathrm{z}$ mapami obecnymi, ale należy zaznaczyć, że część wsi miała położenie inne niż teraz. Przyczyną tych zmian były przede wszystkim reformy agrarne (najpierw związane z uwłaszczeniem chłopów): separacja gruntów, parcelacja i komasacja. Lokalizacja miejscowości przedstawia więc stan z ok. 1800 r. Odniesienie takiego przedstawienia osadnictwa do wieku XVI jest równoznaczne $\mathrm{z}$ zastosowaniem metody retrogresji. Identyfikowanie miejscowości zapisanych w źródłach szesnastowiecznych z miejscowościami oznaczonymi na późniejszych mapach napotyka niekiedy trudności. Dotyczy to m.in. drobnoszlacheckich wsi zwanych okolicami. Zakładano je na podstawie jednego nadania, miały wspólną nazwę ogólną i wspólne granice zewnętrzne, a nie były między sobą rozgraniczone i miały przemieszane pola ${ }^{13}$.

Tutaj można zrobić dygresję na temat niepewności co do identyfikacji starożytnej nazwy miejscowej, której desygnat znany jest jako pierwsza zapisana w źródłach miejscowość na naszych ziemiach. Działający w II stuleciu Klaudiusz Ptolemeusz z Aleksandrii wymienił w swym

\footnotetext{
${ }^{13}$ J. Wiśniewski, Rozwój osadnictwa na pograniczu polsko-rusko-litewskim od końca XIV do połowy XVII wieku, „Acta Baltico-Slavica”, 1, 1964, s. 118-121.
} 
dziele geograficznym nazwę Kalisia. Odnosi się ją do Kalisza, co jest utożsamieniem dyskusyjnym, ale nie ma dowodów, że błędnym ${ }^{14}$. Oprócz samego toponimu za identyfikacją tą przemawiają dwie przesłanki. Po pierwsze, wśród nazw miejscowych, które antyczny autor spisał, podając współrzędne geograficzne, wymienione są punkty położone na bursztynowym szlaku: ujście Wisły, Kalisz, Komarno nad Dunajem (rzymska Kelamantia); odległości wyliczone z szerokości geograficznej tych miejsc wykazują przybliżoną zgodność z rzeczywistością. Po drugie, z rejonu Kalisza znane są liczne źródła archeologiczne z okresu rzymskiego ${ }^{15}$. Oczywiście nie wiadomo, gdzie dokładnie znajdował się starożytny poprzednik miasta założonego w XIII w., ale w średniowieczu topograficzne przesunięcia osiedli zachowujących swą nazwę nie były wyjątkowe ${ }^{16}$.

W legendzie mapy głównej znajduje się znak określony jako „wieś o lokalizacji przybliżonej”, co oznacza dwie różne sytuacje. Po pierwsze, odnosi się do wsi istniejącej w XVI w., której identyfikacja z miejscowością występującą na mapach z XVIII i XIX w. nie jest pewna; po drugie, gdy miejscowość nie występuje na mapach, ale wskazówki o położeniu wsi w XVI w. względem pobliskich osiedli umożliwiają jej przybliżoną lokalizację. Takie oznaczenie stosuje się wówczas, gdy błąd może być większy niż $1 \mathrm{~km}$ w terenie (na mapie: $4 \mathrm{~mm}$ ). Nie przyjmuje się jednak takiego znaku, gdy informacje o położeniu miejscowości są zbyt ogólnikowe, np. tylko jej przynależność parafialna; w takich przypadkach wieś pozostaje niezlokalizowana. Umiejscowienia przybliżonego dotyczy

\footnotetext{
${ }^{14}$ P. Swoboda, Nazewnictwo, w: Wielkopolska, s. 260.

${ }^{15}$ B. Biliński, Kalisia Ptolemeuszowa, „Archeologia”, 5, 1952-1953, s. 101-121; K. Buczek, Dzieje kartografii polskiej od XV do XVIII wieku. Zarys analityczno-syntetyczny, Wrocław 1963, s. 10-12; T. Baranowski, Kalisia - Kalisz, starożytność a wczesne średniowiecze, w: Kalisz na przestrzeni wieków, red. T. Baranowski, A. Buko, Kalisz 2013, s. 81-87.

${ }^{16}$ Por. U. Sowina, T. Związek, T. Panecki, Kalisz w połowie XVI wieku, w: Wielkopolska, s. 313-332.
}

jeszcze drugi znak, objaśniony w legendzie jako „wieś o lokalizacji wiązanej”. Stosuje się go w sytuacji, gdy wiadomo, że dana miejscowość znajdowała się w pobliżu innej, zlokalizowanej. Warto tutaj przytoczyć przykładowe liczby z atlasowego opracowania Wielkopolski, czyli dwóch województw - poznańskiego i kaliskiego. Ustalono, że w drugiej połowie XVI w. istniały na tym obszarze 3784 miejscowości, z których nie udało się zlokalizować 65 (1,7 proc.), 1,3 proc. oznaczono na mapie ze znakiem wsi o lokalizacji przybliżonej, a 2 proc. ze znakiem wsi o lokalizacji wiązanej. W przypadku pozostałych 95 proc. miejscowości położenie na mapie głównej oznaczone zostało zgodnie ze źródłami kartograficznymi.

Co do znacznej części osiedli można mieć pewność, że wiernie wskazano ich położenie w XVI w. Pozwala to stwierdzić np. kościół, który od wielu stuleci niezmiennie stał w jednym miejscu, podobnie dawny dwór lub rynek miasta. W źródłach z XVI w. i wcześniejszych znajdują się różne informacje, które mogą potwierdzać lokalizację. Jeżeli dochodziło gdzieś do przesunięcia wsi, to działo się to $\mathrm{w}$ granicach jednej własności. Przyczyny takich działań mogły być bardzo różne: zmiana koryta rzeki, zniszczenie zabudowy przez pożar, przesiedlenie chłopów w związku z powiększeniem gruntów folwarcznych, lokalna zmiana dróg. Ogólnie jednak wiadomo, że zmiany położenia wsi między końcem XVI a końcem XVIII w. zdarzały się bardzo rzadko ${ }^{17}$. Wydaje się więc, że poprzednie zdania można podsumować następująco: pomijając wsie o lokalizacji przybliżonej, lokalizacja osadnictwa przedstawionego na mapie głównej jest pewna, a ewentualne pojedyncze wyjątki od tej reguły są nieuchwytne ${ }^{18}$.

\footnotetext{
${ }^{17}$ Por. J. Burszta, Od osady słowiańskiej do wsi wspótczesnej, Wrocław 1958, s. 78-108.

${ }^{18}$ H. Rutkowski, Lokalizacja miejscowości, w: Mazowsze, s. 64-76; A. Borek, M Słomski, Lokalizacja miejscowości, w: Wielkopolska, s. 177-202.
} 
Na mapie głównej przedstawione są ważniejsze drogi, które istniały w drugiej połowie XVI w. Na ogół źródła pisane z tego czasu pozwalają oznaczyć tylko niewielkie fragmenty sieci drożnej - występują w nich dość przypadkowo wymienione gościńce, czyli drogi publiczne, określone albo przez powiązanie tylko z jedną miejscowością, albo przez wskazanie dalszego kierunku. Cennym wyjątkiem jest lustracja dróg w województwie krakowskim z 1570 r. ${ }^{19}$ Wobec faktu, że do początku XIX w. przebieg dróg wykazuje znaczną trwałość, główną metodą opracowania jest retrogresja. Oznaczone na mapach z XVIII i XIX w. drogi wyższego rzędu (gościńce, trakty, drogi pocztowe) są podstawą retrogresji połączonej z selekcją. Dokonując wyboru, uwzględnia się informacje o drogach publicznych ze źródeł szesnastowiecznych, o miejscach pobierania cła i myta, o osobnych karczmach, a także ówczesne rozmieszczenie miast, które do XVIII w. niewiele się zmieniło. Przedstawiona sieć ważniejszych dróg należy do bardziej hipotetycznych elementów mapy, i to zarówno pod względem wyboru poszczególnych połączeń, jak też ich przebiegu (chociaż wiele odcinków, np. przy miastach, ma przebieg pewny) ${ }^{20}$.

Kartograficzne odtworzenie granic politycznych i administracyjnych stanowi jeden z podstawowych celów geografii historycznej. W XVI w. głównymi jednostkami podziału administracyjnego Korony były województwa, a także istniejące w niektórych z nich ziemie. Obie te jednostki terytorialne służyły administracji państwowej (stosunkowo słabej) oraz rozwijającemu się samorządowi szlacheckiemu. Województwa i ziemie, które ukształtowały się w ciągu kilku poprzednich stuleci, od wieku

\footnotetext{
${ }^{19}$ Lustracja dróg województwa krakowskiego z roku 1570, wyd. B. Wyrozumska, wstęp K. Buczek, Wrocław 1971.

${ }^{20}$ H. Rutkowski, Drogi, w: Mazowsze, s. 112-120; tenże, Drogi, w: Województwo sandomierskie, s. 121-127; M. Wilska, Drogi, w: Województwo sieradzkie, s. 74-78; taż, Drogi, w: Województwo krakowskie, s. 118-126; T. Związek, Drogi, w: Wielkopolska, s. 268-290.
}

XVI do drugiej połowy XVIII przedstawiały strukturę ustabilizowaną, a ich granice były trwałe. Jeden większy wyjątek stanowiło przyłączenie do województwa krakowskiego w latach 1563-1564 dwóch księstw śląskich - oświęcimskiego i zatorskiego. Najniższą jednostką terytorialną państwa były powiaty, które powstały jako okręgi sądowe stanu szlacheckiego, ale w XVI w. miały także znaczenie administracyjno-skarbowe (w ściąganiu podatków pomocny był również, jak już wspomniano, podział Kościoła katolickiego na parafie). Metodą rekonstrukcji granic na mapie głównej jest interpolacja między osiedlami należącymi do różnych jednostek administracyjnych. Na obszarach o rzadkiej sieci osadniczej trudniej o dokładne oznaczenie granic, czasem jednak umożliwiają to dodatkowe informacje. W słownikach historyczno-geograficznych ziem polskich w średniowieczu dane źródłowe o granicach i drogach są wyodrębnione w osobnym punkcie opisów miejscowości ${ }^{21}$. W miejscach problematycznych pomocna może być retrogresja. Przy pracy nad atlasem korzystano z wydawanych po 1945 r. map administracyjnych powiatów w skali 1:100 000, na których oznaczone zostały granice gmin lub gromad (niekiedy są to granice naturalne). Na wcześniejszych mapach WIG znajduja się informacje o przynależności lasów do określonych majątków. Odtwarzając granice parafii na obszarach niezasiedlonych, uwzględniono przynależność parafialną miejscowości, które powstały po XVI w. Dla odtworzenia granic administracji państwowej wielkie znaczenie mają mapy Perthéesa, gdyż tylko tam przedstawiony został ich przebieg między pierwszym a drugim rozbiorem Rzeczypospolitej ${ }^{22}$.

\footnotetext{
${ }^{21}$ Np. Stownik historyczno-geograficzny województwa krakowskiego w średniowieczu, red. J. Wiśniewski, A. Gąsiorowski, W. Bukowski, Wrocław-Kraków 1980 nn.

${ }^{22}$ A. Dunin-Wąsowiczowa, Podziały administracyjne, w: Mazowsze, s. 35-63; W. Pałucki, Granice i podziały polityczno-administracyjne, w: Województwo sandomierskie, s. 31-49; H. Rutkowski, Granice
} 
Umieszczone w poszczególnych tomach atlasu plany miast są odtworzeniem stanu z XVI w., opartym w większości na źródłach kartograficznych z XIX w., a zatem wykonanym przy zastosowaniu retrogresji.

\section{Z innych opracowań}

W tej części tekstu podajemy przykłady zastosowania metody retrogresji w postaci map, które pozwalają wyjaśnić, jak ich autorzy przedstawiali wyniki swoich badań w formie kartograficznej.

Obejmująca większość terytorium Wielkopolski mapa 2 to przedruk z pracy Stanisława Arnolda pt. Terytoria plemienne $w$ ustroju administracyjnym Polski Piastowskiej ${ }^{23}$. Celem autora było odtworzenie ziem z XII i XIII w., w których upatrywał terytoriów plemiennych z X w. (zasięg ziem oznaczony jest pasami w formie kresek). Rekonstruując granice kasztelanii, korzystał z bezpośrednich informacji źródłowych z owego czasu, ale w dużym stopniu posługiwał się też retrogresją od wieku XVI (gdy chodziło o granice archidiakonatów i powiatów). Praca Arnolda wzbudziła szeroką, długotrwałą dyskusję i odegrała wielką rolę w studiach nad geografią polityczną średniowiecznej Polski, w szczególności nad kasztelaniami. Wobec rozwoju badań znaczenie tego tekstu zmalało, ale wydaje się, że nie zanikło ${ }^{24}$. Omawiane wyżej mapy główne w serii „Atlas historyczny Polski. Mapy szczegółowe XVI wieku” pozwalają dostrzec osiągnięcia i błędy Arnolda w przedstawianiu granic administracji państwowej i kościelnej z tamtego stulecia.

państwowych jednostek terytorialnych, w: Województwo sieradzkie, s. 26-29; tenże, Granice państwowych jednostek terytorialnych, w: Województwo krakowskie, s. 27-35; M. Gochna, Granice państwowych jednostek terytorialnych, w: Wielkopolska, s. 46-64.

${ }^{23}$ S. Arnold, Terytoria plemienne w ustroju administracyjnym Polski Piastowskiej (w. XII-XIII), „Prace Komisji dla Atlasu Historycznego Polski", 2, 1927, s. 1-126, cztery mapy w skali 1:1000 000, w tym mapa po s. 48: Wielkopolska (w. XII-XIV).

${ }^{24}$ T. Giergiel, Problematyka badawcza i metody rekonstrukcji krajobrazu historyczno-politycznego - przykład kasztelanii, w: Nauki pomocnicze historii. Teoria, metody badań, dydaktyka, red. A. Jaworska, R. Jop, Warszawa 2013, s. 211-237.
Pochodząca z pracy Karola Buczka pt. Ziemie polskie przed tysiacem lat ${ }^{25}$ mapa 3 nosi tytuł Próba rekonstrukcji krajobrazu Polski wczesnohistorycznej. W jej legendzie widnieją cztery oznaczenia: obszary podmokłe i torfowiska, krajobraz puszczowy, krajobraz leśno-polny oraz krajobraz polno-leśny (parkowy), a opisywane przez nie formacje osadniczo-krajobrazowe zazębiają się na mapie. Autor określił, że jej ramy czasowe sięgają połowy XIII w., a przedstawiony obraz kartograficzny nazwał hipotetycznym, ponieważ opierał się w pracy na danych pośrednich i źródłach z czasów późniejszych. Według map z przełomu XVIII i XIX w. pokazane zostały w szczególności puszcze. Karol Buczek podkreślił, że „nie można oczekiwać po tej rekonstrukcji niczego więcej, jak tylko ogólnej orientacji. Tę zaś da się niewątpliwie osiagnąć na tej drodze, przy takim bowiem ujęciu zagadnienia drobne błędy nie mogą zmienić istoty rzeczy [...]"26.

Mapa 4, obejmująca południowo-zachodnie pogranicze powiatu grodzieńskiego w XVI w., jest częścią większej mapy Jana Jakubowskiego ${ }^{27}$. Zalesienie z XVI w. oznaczone jest na niej kolorem zielonym dwojako: obszary pokryte płaszczyznowo przedstawiaja lasy według wydanej w 1808 r. w Berlinie mapy Jana K. Textora, która obejmuje tzw. Nowe Prusy Wschodnie; obszary zakreskowane to natomiast lasy odtworzone przez autora z wykorzystaniem „rozciągłości puszcz królewskich na podstawie Rewizji puszcz z r. 1559"28. Oznaczone na mapie miejscowości wymienione zostały w indeksie wraz z odesłaniem do źródeł; białe plamy pokazują z kolei tereny, odnośnie do których brak danych o osadnictwie. Późniejsi autorzy wskazali,

\footnotetext{
${ }^{25} \mathrm{~K}$. Buczek, Ziemie polskie przed tysiącem lat (zarys geograficzno-historyczny), Wrocław 1960, wklejka [mapa w skali ok. 1:3000 000], s. 15-30 [objaśnienie mapy].

${ }^{26}$ Tamże, s. 27.

${ }^{27}$ J. Jakubowski, Powiat grodzieński w w. XVI, „Prace Komisji Atlasu Historycznego Polski”, 3, 1935, s. 99-114, mapa załącznikowa w skali 1:400 000 .

${ }^{28}$ Tamże, s. 100.
} 


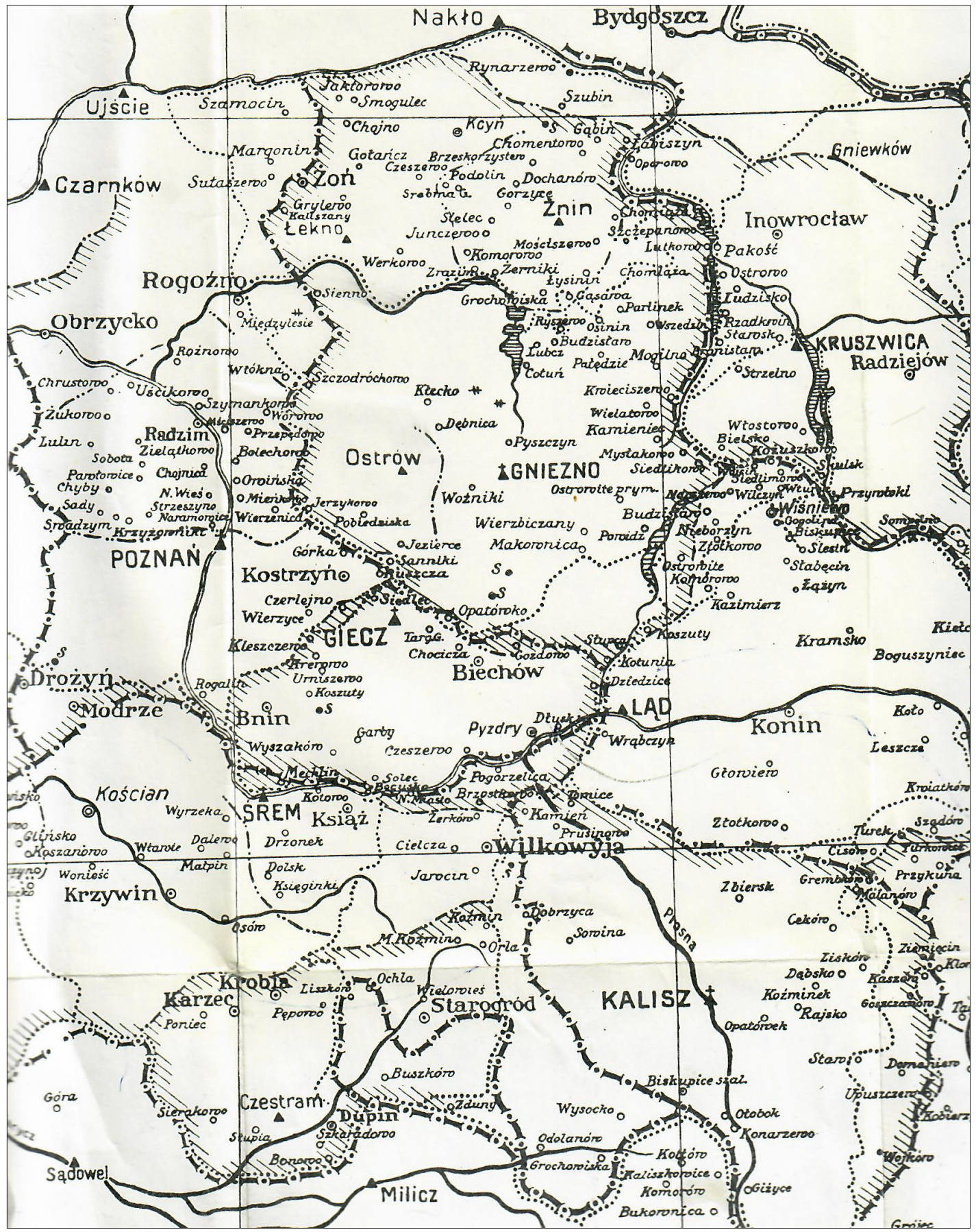

Mapa 2. Fragment mapy Wielkopolski średniowiecznej autorstwa Stanisława Arnolda 


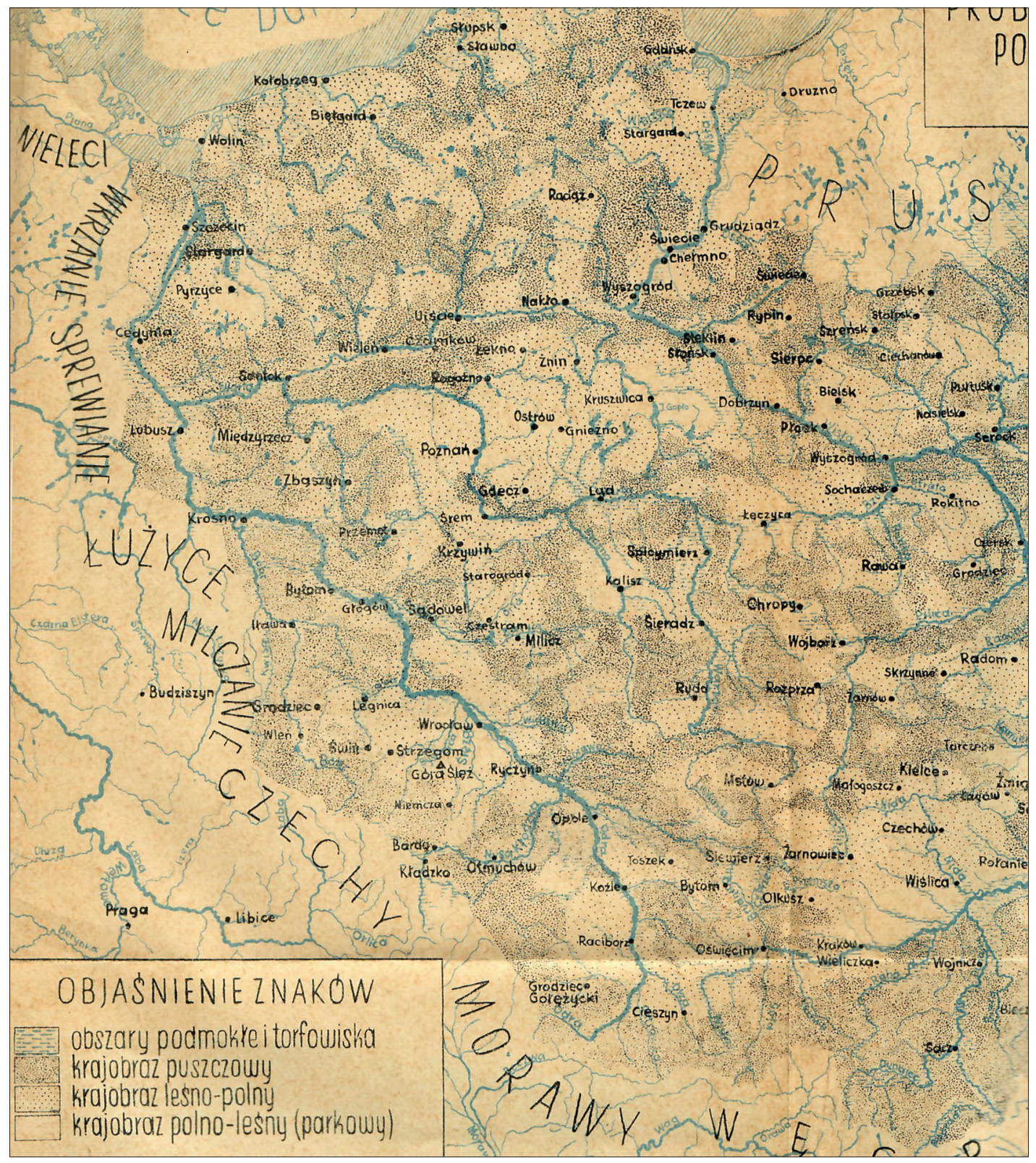

Mapa 3. Fragment mapy Polski do połowy XIII w. autorstwa Karola Buczka

że Jakubowski nie wykorzystał pełnej podstawy źródłowej do tego tematu ${ }^{29}$.

Przedstawiająca część granicy polsko-litewskiej w 1784 r. mapa 5 pochodzi z mo-

${ }^{29}$ G. Błaszczyk, Geografia historyczna Wielkiego Księstwa Litewskiego, Poznań 2012, s. 90. jego artykułu o rozgraniczeniu z $1358 \mathrm{r}^{30}$ Zgodnie z wcześniejszymi opracowaniami przyjąłem, że granica z XIV w. przetrwała

${ }^{30}$ H. Rutkowski, Granica mazowiecko-litewska między Wizną a Grodnem z 1358 r., „Studia Geohistorica”, 5, 2017, s. 140-155, mapa na s. 149. Zob. także polemikę Elżbiety Kowalczyk-Heyman i moją odpowiedź w niniejszym tomie na stronach 213-233. 


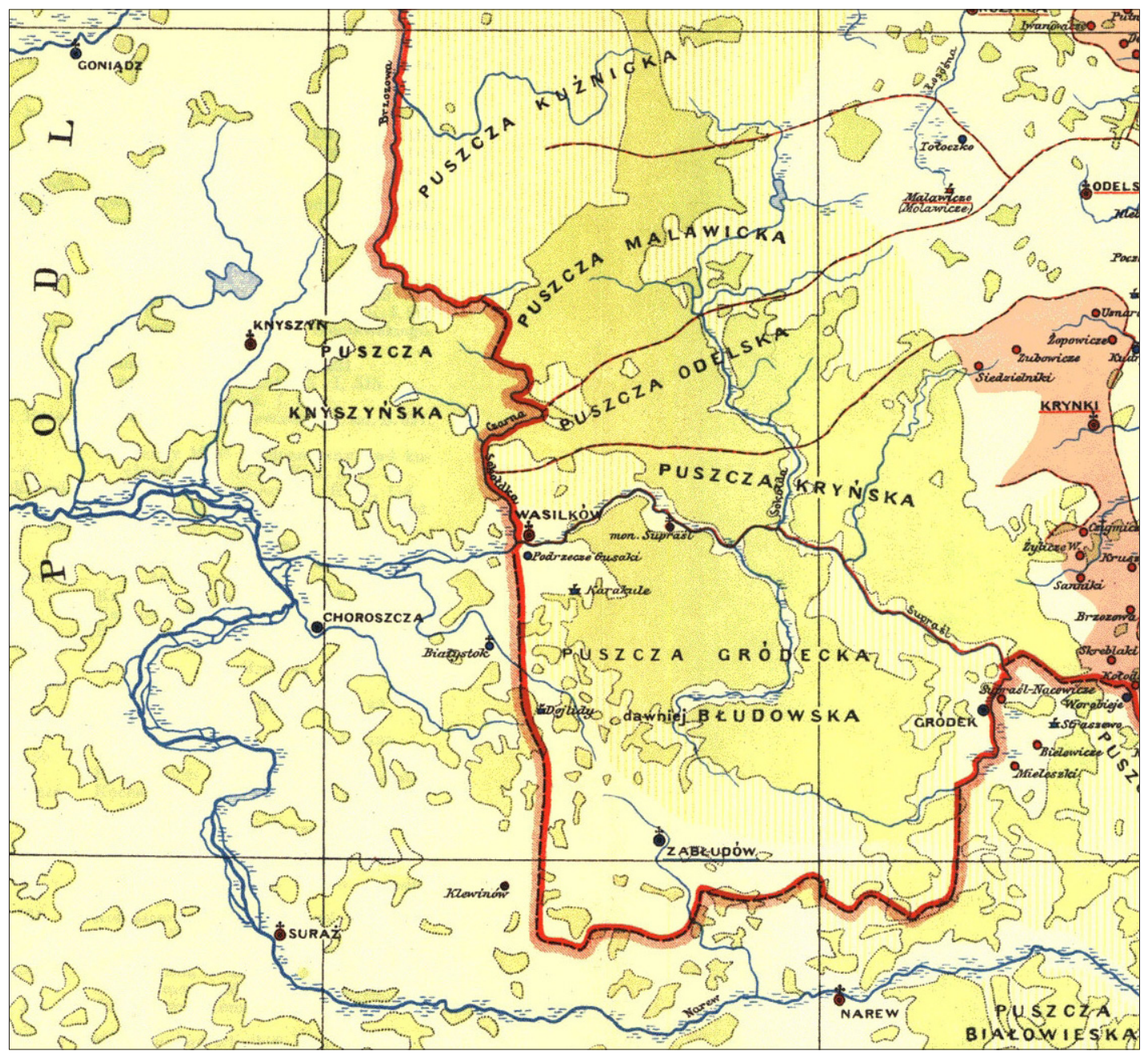

Mapa 4. Fragment mapy powiatu grodzieńskiego w XVI w. Jana Jakubowskiego

jako rozgraniczenie między Koroną a Litwą od 1569 r. do rozbiorów Rzeczypospolitej. W 1358 r. książę litewski Kiejstut wystawił w Grodnie dokument, w którym zawarł z księciem mazowieckim Siemowitem III układ ustalający granicę między ziemiami Litwy i Mazowsza na podstawie tego, co stwierdzili w terenie pełnomocnicy obu stron. Wobec odcinka objętego tą mapą dokument stwierdza, że granica od Popielowego Siedliska biegnie bezpośrednio do Niewodnicy Uścia. Przypuszczam, że Popielowe Siedlisko to obecnie wieś Sielachowskie, a Niewodnica Uście znaczy to samo, co Niewodnica Wypływ, czyli początek rzeki Niewodnicy (w rejonie wsi Skrybicze i Niewodnica Nargilewska). Gdyby uznać, że między XIV a XVIII w. wraz z rozwojem osadnictwa doszło w tym rejonie do przesunięcia granicy na korzyść strony litewskiej, to zapewne należałoby poprowadzić przybliżoną granicę z $1358 \mathrm{r}$. tak, jak pokazuje prosta linia dodana na tej mapie. Opowiadam się jednak za retrogresją także na tym odcinku.

Mapa 6 jest przedstawieniem całej granicy, którą uzgodniono w 1358 r. $^{31}$

${ }^{31}$ H. Rutkowski, Granica, mapa na s. 147. 


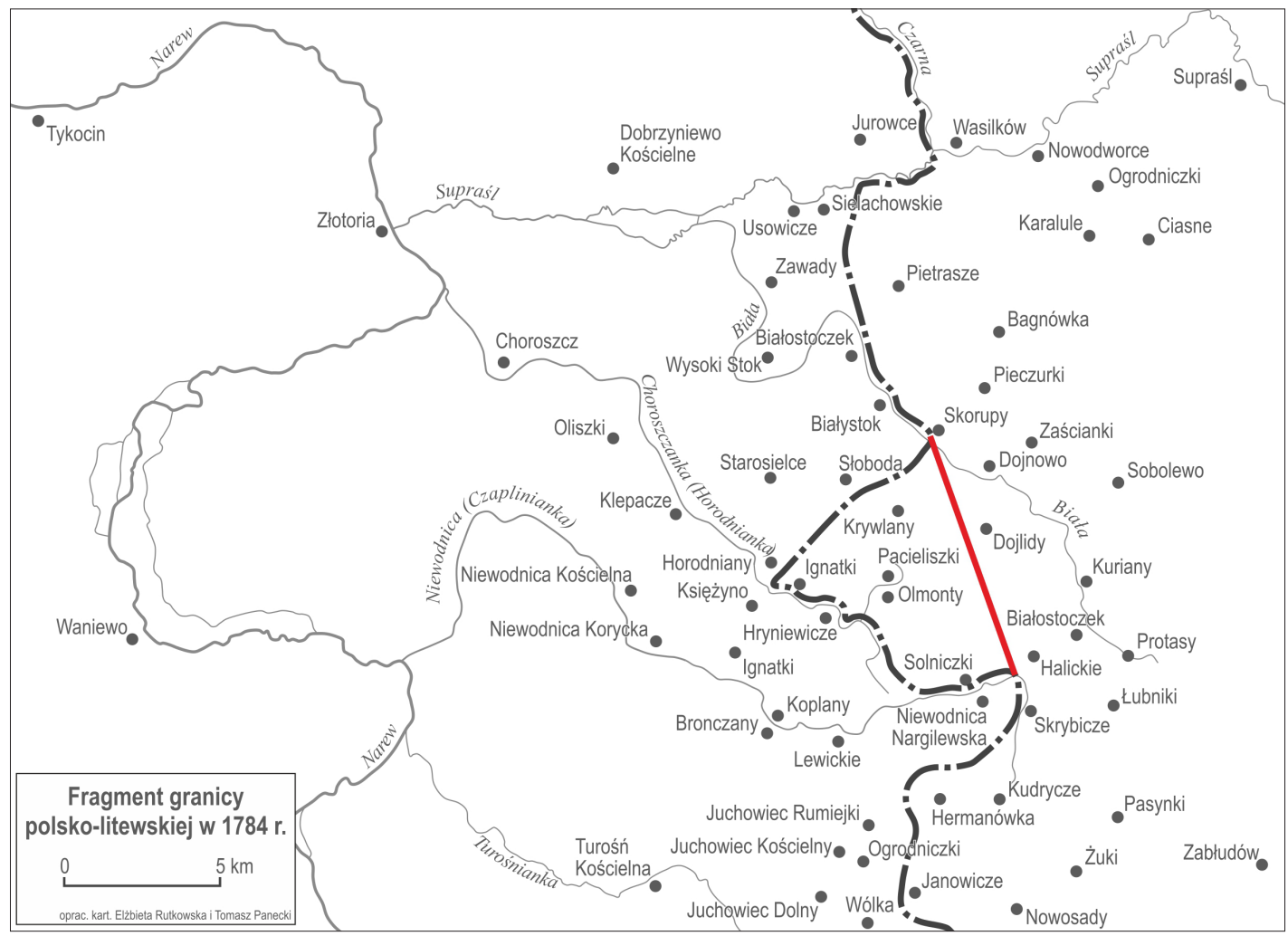

Mapa 5. Fragment granicy polsko-litewskiej w 1784 r.

Rozpatrzenie tego zagadnienia potwierdziło występującą w literaturze przedmiotu opinię, że granica ustalona w znacznej większości wzdłuż rzek nie uległa zmianie do roku 1795. Stwierdzenie to nie dotyczy początkowego odcinka między rzekami Ełk i Netta, który nie został zrealizowany. Odnosi się natomiast do odcinka końcowego na południe od Supraśli (mapa 5), który inni badacze przedstawiają odmiennie. Sądzę, że jest to przykład zastosowania retrogresji, która ma mocne uzasadnienie w źródłach zarówno z XIV, jak i XVIII w.

Mapa 7 stanowi wycinek mapy województwa lubelskiego opracowanej przez Karola Perthéesa w roku 1786, a wydrukowanej przed 1806 . W przeciwieństwie do poprzednich przykładów stosowania retrogresji ten nie był jeszcze publikowany. Dotyczy on wydarzenia o rok późniejszego niż wymieniony wyżej dokument Kiejstuta. W 1359 r. doszło do porozumienia co do granicy między ziemią lubelską (należącą do Polski) i ziemią chełmską (etnicznie ruską, a politycznie znajdującą się pod władzą litewska). Na polecenie króla Kazimierza Wielkiego i księcia chełmskiego Jerzego ${ }^{32}$ starosta ziemi lubelskiej Grot z Chrobrzan oraz wojewoda i starosta ziemi chełmskiej Andrzej Szerkalicz z Krupego ustanowili granicę między tymi ziemiami na określonym odcinku ${ }^{33}$. Z dokumentu wynika, że

\footnotetext{
${ }^{32}$ Przeważa pogląd, że był to Jerzy Narymuntowicz, ale niektórzy historycy opowiadają się za Jerzym Koriatowiczem. Zob. J. Wyrozumski, Kazimierz Wielki, Wrocław 1986, s. 93-94, 98-99; G. Błaszczyk, Dzieje stosunków polsko-litewskich od czasów najdawniejszych do wspótczesności, t. 1: Trudne początki, Poznań 1998, s. 158-159; J. Tęgowski, Pierwsze pokolenia Giedyminowiczów, Poznań-Wrocław 1999, s. 34-36, 164, 167-168.

${ }^{33}$ Zbiór dokumentów małopolskich, cz. 4, wyd. S. Kuraś, I. Sułkowska-Kurasiowa, Wrocław 1969, nr 961, s. 113-115. Por. S. Bylina, Drogi, granice, most. Studia o przestrzeni publicznej i sakralnej w średniowieczu, Warszawa 2012, s. 80.
} 


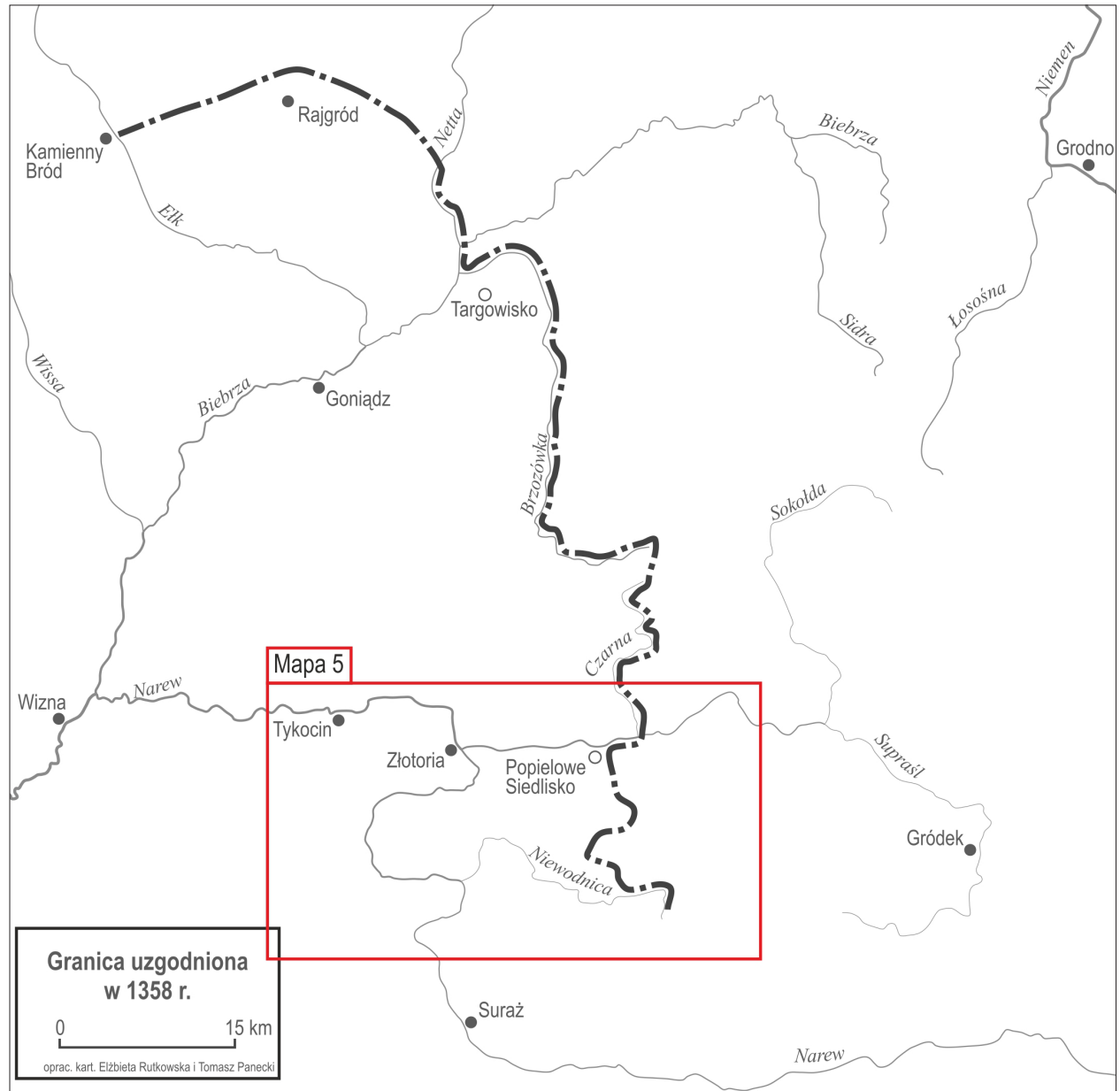

Mapa 6. Granica mazowiecko-litewska uzgodniona w 1358 r.

istniała ona w tym rejonie już wcześniej, ponieważ wzmiankowane są śladogonie, czyli granice oznakowane ${ }^{34}$. W 1359 r. nastąpiło więc prawdopodobnie tylko potwierdzenie jej przebiegu (być może z jakimiś lokalnymi zmianami). Z każdej strony wymieniono tam cztery wsie, które są tak samo położone $\mathrm{w}$ stosunku do granicy lubelsko-chełmskiej na mapie Perthéesa. Na zaproponowanej tu reprodukcji mapy oznaczenie granicy wzmocnione zostało kolorem, a miejscowości z dokumentu otoczono ramkami. W ziemi lubelskiej są to: Oleśniki, Suchodoły (na mapie widnieje Karczma Suchodolska), Częstoborowice i Pilaszkowice; w ziemi chełmskiej natomiast: Dobryniów, Stężyca, Gorzków i Żółkiew (na mapie: Żółkiewka). Między XIV a XVIII w. przybyły nowe miejscowości, ale można sądzić, że granica - pierwotnie państwowa, a następnie administracyjna - przetrwała przez stulecia bez zmian. W takiej sytuacji retrogresja daje wynik pewny.

${ }^{34}$ Stownik staropolski, t. 9, red. S. Urbańczyk i in., Wrocław 1982, s. $10-11$. 


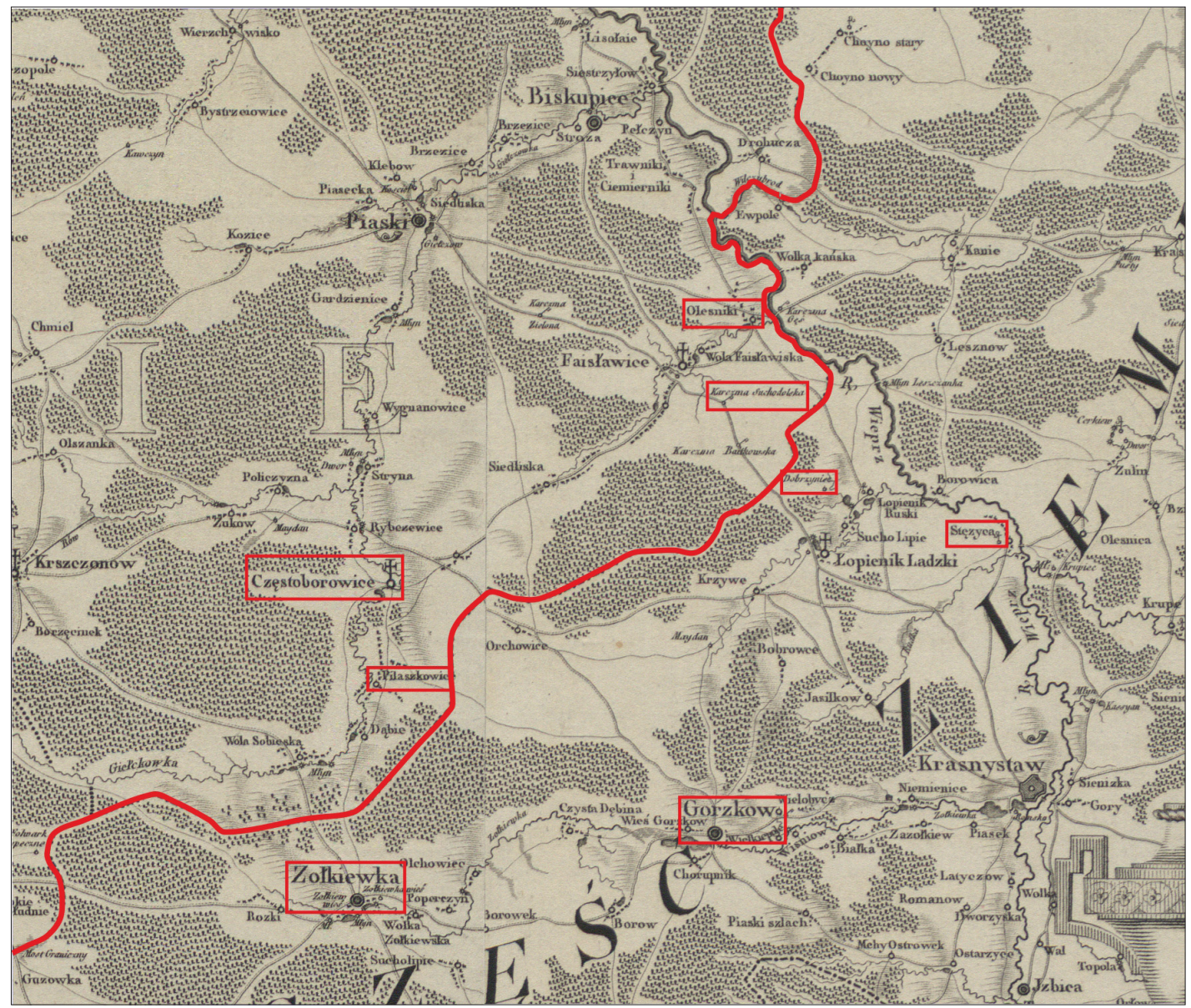

Mapa 7. Fragment mapy województwa lubelskiego Karola Perthéesa z 1786 r.

\section{Uwagi końcowe}

W kartografii historycznej pierwszeństwo mają źródła z badanego okresu, a nie źródła późniejsze, które stanowią podstawę retrogresji. Elementy dawnego krajobrazu oznaczane na mapach przy zastosowaniu metody retrogresji mają różny stopień pewności lub prawdopodobieństwa. Zależy to nie tylko od podstawy źródłowej, lecz także od skali map. Mapa pokazuje szczegóły trudne albo nawet niemożliwe do opisania w tekście, w nim zaś można dokładniej wyjaśnić stopień pewności różnych elementów przedstawienia kartograficznego. Powstaje zatem pytanie, w jakich przypadkach zróżnicowanie oznaczeń w treści mapy, które jest odpowiednio objaśnione w legendzie, można uznać za wystarczające, a kiedy i w jakim zakresie niezbędny jest tekst komentarza. Nie ulega natomiast wątpliwości, że zasady stosowania metody retrogresji w przedstawieniach kartograficznych wymagają dyskusji. 


\section{Bibliografia}

Arnold S., Geografia historyczna, jej zadania i metody, „Przegląd Historyczny”, 28 (1), 1929.

Arnold S., Terytoria plemienne w ustroju administracyjnym Polski Piastowskiej (w. XII-XIII), „Prace Komisji dla Atlasu Historycznego Polski”, 2, 1927.

Baranowski T., Kalisia - Kalisz, starożytność a wczesne średniowiecze, w: Kalisz na przestrzeni wieków, red. T. Baranowski, A. Buko, Kalisz 2013.

Biliński B., Kalisia Ptolemeuszowa, „Archeologia”, 5, 1952-1953.

Błaszczyk G., Dzieje stosunków polsko-litewskich od czasów najdawniejszych do wspótczesności, t. 1: Trudne początki, Poznań 1998.

Błaszczyk G., Geografia historyczna Wielkiego Księstwa Litewskiego, Poznań 2012.

Borek A., Słomski M., Lokalizacja miejscowości, w: Wielkopolska w drugiej potowie XVI wieku, red. K. Chłapowski, M. Słoń, oprac. A. Borek i in., Warszawa 2017 (Atlas historyczny Polski. Mapy szczegółowe XVI wieku, 4).

Buczek K., Dzieje kartografii polskiej od XV do XVIII wieku. Zarys analityczno-syntetyczny, Wrocław 1963.

Buczek K., Ziemie polskie przed tysiacem lat (zarys geograficzno-historyczny), Wrocław 1960.

Burszta J., Od osady stowiañskiej do wsi wspótczesnej, Wrocław 1958.

Bylina S., Drogi, granice, most. Studia o przestrzeni publicznej i sakralnej w średniowieczu, Warszawa 2012.

Chłapowski K., Środowisko geograficzne, w: Województwo sandomierskie w drugiej potowie XVI wieku, red. W. Pałucki, oprac. K. Chłapowski i in., Warszawa 1993 (Atlas historyczny Polski. Mapy szczegółowe XVI wieku, 2).

Dunin-Wąsowiczowa A., Podziaty administracyjne, w: Mazowsze w drugiej potowie XVI wieku, red. A. Pałucki, oprac. A. Dunin-Wąsowiczowa i in., Warszawa 1973 (Atlas historyczny Polski. Mapy szczegółowe XVI wieku, 7).

Giergiel T., Problematyka badawcza i metody rekonstrukcji krajobrazu historyczno-politycznego - przyktad kasztelanii, w: Nauki pomocnicze historii. Teoria, metody badań, dydaktyka, red. A. Jaworska, R. Jop, Warszawa 2013.

Gieysztor A., Zarys nauk pomocniczych historii, t. 2, Warszawa 1948.

Gochna M., Granice państwowych jednostek terytorialnych, w: Wielkopolska w drugiej potowie XVI wieku, red. K. Chłapowski, M. Słoń, oprac. A. Borek i in., Warszawa 2017 (Atlas historyczny Polski. Mapy szczegółowe XVI wieku, 4).

Humnicki J., Pacuski K., Srodowisko geograficzne, w: Mazowsze w drugiej potowie XVI wieku, red. A. Pałucki, oprac. A. Dunin-Wąsowiczowa i in.,
Warszawa 1973 (Atlas historyczny Polski. Mapy szczegółowe XVI wieku, 7).

Jakubowski J., Powiat grodzieński w w. XVI, „Prace Komisji Atlasu Historycznego Polski”, 3, 1935.

Kalisz na przestrzeni wieków, red. T. Baranowski, A. Buko, Kalisz 2013.

Lustracja dróg województwa krakowskiego z roku 1570, wyd. B. Wyrozumska, wstęp K. Buczek, Wrocław 1971.

Mazowsze w drugiej potowie XVI wieku, red. A. Pałucki, oprac. A. Dunin-Wąsowiczowa i in., Warszawa 1973 (Atlas historyczny Polski. Mapy szczegółowe XVI wieku, 7).

Nauki pomocnicze historii. Teoria, metody badan, $d y$ daktyka, red. A. Jaworska, R. Jop, Warszawa 2013.

Pałucki W., Granice i podziaty polityczno-administracyjne, w: Województwo sandomierskie w drugiej potowie XVI wieku, red. W. Pałucki, oprac. K. Chłapowski i in., Warszawa 1993 (Atlas historyczny Polski. Mapy szczegółowe XVI wieku, 2).

Panecki T., Zródta kartograficzne, w: Wielkopolska $w$ drugiej potowie XVI wieku, red. K. Chłapowski, M. Słoń, oprac. A. Borek i in., Warszawa 2017 (Atlas historyczny Polski. Mapy szczegółowe XVI wieku, 4).

Rutkowska E., Środowisko geograficzne, w: Wielkopolska $w$ drugiej potowie XVI wieku, red. K. Chłapowski, M. Słoń, oprac. A. Borek i in., Warszawa 2017 (Atlas historyczny Polski. Mapy szczegółowe XVI wieku, 4).

Rutkowska E., Środowisko geograficzne, w: Województwo krakowskie w drugiej potowie XVI wieku, red. H. Rutkowski, oprac. K. Chłapowski i in., Warszawa 2008 (Atlas historyczny Polski. Mapy szczegótowe XVI wieku, 1).

Rutkowski H., Drogi, w: Mazowsze w drugiej potowie $X V I$ wieku, red. A. Pałucki, oprac. A. Dunin-Wąsowiczowa i in., Warszawa 1973 (Atlas historyczny Polski. Mapy szczegółowe XVI wieku, 7).

Rutkowski H., Drogi, w: Województwo sandomierskie $w$ drugiej potowie XVI wieku, red. W. Pałucki, oprac. K. Chłapowski i in., Warszawa 1993 (Atlas historyczny Polski. Mapy szczegółowe XVI wieku, 2).

Rutkowski H., Fundamenta historiae. Pisma wybrane, red. M. Zbieranowski, M. Słoń, Warszawa 2014.

Rutkowski H., Granica mazowiecko-litewska między Wizna a Grodnem z 1358 r., „Studia Geohistorica”, 5, 2017, s. 140-155.

Rutkowski H., Granice panistwowych jednostek terytorialnych, w: Województwo krakowskie w drugiej potowie XVI wieku, red. H. Rutkowski, oprac. K. Chłapowski i in., Warszawa 2008 (Atlas historyczny Polski. Mapy szczegółowe XVI wieku, 1). 
Rutkowski H., Granice państwowych jednostek terytorialnych, w: Województwo sieradzkie i województwo tęczyckie w drugiej potowie XVI wieku, red. H. Rutkowski, oprac. K. Chłapowski i in., Warszawa 1998 (Atlas historyczny Polski. Mapy szczegółowe XVI wieku, 5).

Rutkowski H., Lokalizacja miejscowości, w: Mazowsze $w$ drugiej potowie XVI wieku, red. A. Pałucki, oprac. A. Dunin-Wąsowiczowa i in., Warszawa 1973 (Atlas historyczny Polski. Mapy szczegółowe XVI wieku, 7).

Rutkowski H., Mapy Perthéesa, w: H. Rutkowski, Fundamenta historiae. Pisma wybrane, red. M. Zbieranowski, M. Słoń, Warszawa 2014.

Rutkowski H., Prace nad atlasem historycznym Polski XVI wieku, „Polish Cartographical Review. Suplement w języku polskim”, 3 (2), 2018.

Rutkowski H., Stanistaw Herbst (1907-1973), w: Szkoty, ośrodki i twórcy polskiej historii kartografii (1945-2015), red. T. Bogacz, B. Konopska, Warszawa 2016 (Z Dziejów Kartografii, 20).

Rutkowski H., Work on the historical atlas of the sixteenth-century Poland, „Polish Cartographical Review”, 50 (4), 2018.

Rutkowski H., Źródta kartograficzne, w: H. Rutkowski, Fundamenta historiae. Pisma wybrane, red. M. Zbieranowski, M. Słoń, Warszawa 2014.

Słoń M., Źródta pisane, w: Wielkopolska w drugiej potowie XVI wieku, red. K. Chłapowski, M. Słoń, oprac. A. Borek i in., Warszawa 2017 (Atlas historyczny Polski. Mapy szczegółowe XVI wieku, 4).

Stownik historyczno-geograficzny województwa krakowskiego w średniowieczu, red. J. Wiśniewski, A. Gąsiorowski, W. Bukowski, Wrocław-Kraków 1980 nn.

Stownik staropolski, t. 9, red. S. Urbańczyk i in., Wrocław 1982.

Sowina U., Związek T., Panecki T., Kalisz w potowie XVI wieku, w: Wielkopolska w drugiej potowie XVI wieku, red. K. Chłapowski, M. Słoń, oprac. A. Borek i in., Warszawa 2017 (Atlas historyczny Polski. Mapy szczegółowe XVI wieku, 4).

Swoboda P., Nazewnictwo, w: Wielkopolska w drugiej połowie XVI wieku, red. K. Chłapowski, M. Słoń, oprac. A. Borek i in., Warszawa 2017 (Atlas historyczny Polski. Mapy szczegółowe XVI wieku, 4).

Szkoty, ośrodki i twórcy polskiej historii kartografii (19452015), red. T. Bogacz, B. Konopska, Warszawa 2016 (Z Dziejów Kartografii, 20).

Tęgowski J., Pierwsze pokolenia Giedyminowiczów, Poznań-Wrocław 1999.

Topolski J., Metodologia historii, Warszawa 1968.
Wielkopolska w drugiej potowie XVI wieku, red. K. Chłapowski, M. Słoń, oprac. A. Borek i in., Warszawa 2017 (Atlas historyczny Polski. Mapy szczegółowe XVI wieku, 4).

Wilska M., Drogi, w: Województwo krakowskie w drugiej potowie XVI wieku, red. H. Rutkowski, oprac. K. Chłapowski i in., Warszawa 2008 (Atlas historyczny Polski. Mapy szczegółowe XVI wieku, 1).

Wilska M., Drogi, w: Województwo sieradzkie i województwo tęczyckie $w$ drugiej potowie XVI wieku, red. H. Rutkowski, oprac. K. Chłapowski i in., Warszawa 1998 (Atlas historyczny Polski. Mapy szczegółowe XVI wieku, 5).

Wilska M., Środowisko geograficzne, w: Województwo sieradzkie i województwo tęczyckie $w$ drugiej potowie XVI wieku, red. H. Rutkowski, oprac. K. Chłapowski i in., Warszawa 1998 (Atlas historyczny Polski. Mapy szczegółowe XVI wieku, 5).

Wiśniewski J., Rozwój osadnictwa na pograniczu polsko-rusko-litewskim od końca XIV do potowy XVII wieku, „Acta Baltico-Slavica”, 1, 1964.

Województwo krakowskie $w$ drugiej potowie XVI wieku, red. H. Rutkowski, oprac. K. Chłapowski i in., Warszawa 2008 (Atlas historyczny Polski. Mapy szczegółowe XVI wieku, 1).

Województwo lubelskie w drugiej potowie XVI wieku, red. W. Pałucki, oprac. S. Wojciechowski, Warszawa 1966 (Atlas historyczny Polski. Mapy szczegółowe XVI wieku, 3).

Województwo ptockie okoto 1578 r., red. S. Herbst, oprac. I. Gieysztorowa i in., Wrocław 1958 (Atlas historyczny Polski. Seria A: Mapy szczegółowe, 2).

Województwo sandomierskie w drugiej potowie XVI wieku, red. W. Pałucki, oprac. K. Chłapowski i in., Warszawa 1993 (Atlas historyczny Polski. Mapy szczegółowe XVI wieku, 2).

Województwo sieradzkie i województwo tęczyckie w drugiej potowie XVI wieku, red. H. Rutkowski, oprac. K. Chłapowski i in., Warszawa 1998 (Atlas historyczny Polski. Mapy szczegółowe XVI wieku, 5).

Wyrozumski J., Kazimierz Wielki, Wrocław 1986.

Zbiór dokumentów matopolskich, cz. 4, wyd. S. Kuraś, I. Sułkowska-Kurasiowa, Wrocław 1969.

Związek T., Drogi, w: Wielkopolska w drugiej potowie $X V I$ wieku, red. K. Chłapowski, M. Słoń, oprac. A. Borek i in., Warszawa 2017 (Atlas historyczny Polski. Mapy szczegółowe XVI wieku, 4).

Związek T., Panecki T., Osadnictwo olęderskie w badaniach nad rekonstrukcja szesnastowiecznego zalesienia na przyktadzie okolic Nowego Tomyśla, „Studia Geohistorica”, 5, 2017. 


\section{The Retrogressive Method in Historical Geography of Poland (Selected Problems)}

\section{Summary}

One of the attributes of historical geography is the broad usage of retrogressive method, i.e. determining previous facts on the basis of subsequent facts. In classic approach, this method is applied along with the usage of direct data from researched period, which leads to definite or plausible results. In case of historical cartography, a major role on the level of certainty of the outcomes has the scale of the map: on those more detailed this level is lower, on those made in small scale the result could be defined as definite.

The first part of the article depicts the experience gained during the elaboration of the detailed map of Poland in the $16^{\text {th }}$ century. It is the main map in the "Historical Atlas of Poland", six volumes (of eight planned) of which were published from 1966 to 2017 . The scale of the map is $1: 250000$. It shows all settlements existing in the second half of the $16^{\text {th }}$ century. The starting point for using the retrogressive method was, in this case, the end of the $18^{\text {th }}$ and the early $19^{\text {th }}$ century. By using maps from this period, the network of rivers and lakes were drawn with necessary changes based on the prior sources. As a whole, one can say that the network of waters is reconstructed with the retrogressive method as it was in the $16^{\text {th }}$ century (the courses of small rivers are almost certain, the courses of big ones are plausible). The reconstructed map shows forests as they were depicted on the maps from the end of the $18^{\text {th }}$ and the early $19^{\text {th }}$ century. Those maps also formed the basis for a reconstruction of the localisation of a settlement. The vast majority of settlements from the $16^{\text {th }}$ century has a definite localisation on the reconstructed map, but in some cases their location is estimated. Individual exceptions from this rule are intangible. Less definite is the road network. Borders of the state and Church administrative units were reconstructed by using the interpolation between the settlements from different units and by usage of later maps.

In the second part of the text examples of the application of the retrogressive method are shown.

Henryk Rutkowski - emerytowany pracownik Instytutu Historii im. Tadeusza Manteuffla Polskiej Akademii Nauk, współpracownik Zakładu Atlasu Historycznego w tym instytucie. Zajmuje się historią Polski XII-XVIII w., zwłaszcza dziejami miast, geografią historyczną i historią kartografii (h.rutkowski@ihpan.edu.pl)

Henryk Rutkowski - retired employee of The Tadeusz Manteuffel Institute of History, Polish Academy of Sciences, researcher at the Department of the Historical Atlas of the Institute. His research interests cover the history of Poland in the $12^{\text {th }}-18^{\text {th }}$ centuries, especially history of towns and cities, historical geography and history of cartography (h.rutkowski@ihpan.edu.pl) 